University of Windsor

Scholarship at UWindsor

$1-1-2003$

\title{
Some Adventures of the Boys: Enniskillen Township's "Foreign \\ Drillers," Imperialism, and Colonial Discourse, 1873-1923
}

Christina Ann Burr

University of Windsor

Follow this and additional works at: https://scholar.uwindsor.ca/historypub

Part of the History Commons

\section{Recommended Citation}

Burr, Christina Ann. (2003). Some Adventures of the Boys: Enniskillen Township's "Foreign Drillers," Imperialism, and Colonial Discourse, 1873-1923. Labour / Le Travail, 51, 47-79.

https://scholar.uwindsor.ca/historypub/26

This Article is brought to you for free and open access by the Department of History at Scholarship at UWindsor. It has been accepted for inclusion in History Publications by an authorized administrator of Scholarship at UWindsor. For more information, please contact scholarship@uwindsor.ca. 


\title{
Some Adventures of the Boys: Enniskillen Township's "Foreign Drillers," Imperialism, and Colonial Discourse, 1873-1923
}

\author{
Christina Burr
}

IN DECEMBER 1873 the first crew of Enniskillen township's "foreign drillers" left the small oil-producing town of Petrolia, located in the centre of Lambton County in southwestem Ontario. The drilling crew consisted of oil engineer Malcolm "Mall" Scott, scaffold man William Covert, and drillers Joshua Porter and Edward Cook. Their destination was the Dutch colony of Tjibodas, located at the foot of the volcano Tjarema, south of Cheribon in West Java. In a scene that would be repeated numerous times over the next 50 years, as drillers from Enniskillen township departed for what were referred to locally as "foreign fields," friends and family gathered at the train station to see the men off. The men departed to the strains of the old Scottish song "Will Ye No Come Back Again" played by the town band. ${ }^{1}$ Ten months later, the local Petrolia newspaper, the Petrolia Advertiser, published extracts from a personal letter from one of the drillers, Joshua Porter, to his brother Joseph. The letter was composed on 17 July 1874, shortly after the crew of drillers arrived at Tjibodas. Porter's verbal painting of the landscape produced for the home audience a sweeping visual mastery of the scene, which Mary Pratt describes in her study Imperial Eyes as "the monarch-of-all-I-survey scene." The East India Islands were depicted by Porter as showing much promise for Western development,

${ }^{1}$ Victor Lauriston, "The Town of World Travelers," Maclean's Magazine (1 May 1924), 18. Unfortunately the issue of the Petrolia Advertiser containing a description of their departure is no longer extant.

${ }^{2}$ Mary Louise Pratt, Imperial Eyes: Travel Writing and Transculturation (London and New York 1992), 201-27.

Christina Burr, "Some Adventures of the Boys: Enniskillen Township's 'Foreign Drillers,' Imperialism, and Colonial Discourse, 1873-1923," Labour/Le Travail, 51 (Spring 2003), 47-80. 
"being covered with rich vegetation, from the mountain top to the waters edge." Consistent with the narratives of 19th century European travel writers, Porter's mapping of Batavia, Java (the present day city of Jakarta, Indonesia) reinforced European racial hierarchies. "The hotels are numerous and grand buildings, always back from the streets and surrounded by gorgeous grounds, giving an appearance of rich private residences," Porter reported. "The European stores," he continued, "are built in the same style, but the Chinese shops and native markets are a curiosity." The mapping of non-white Eastem Others as a "curiosity" highlights the "mastery" of white Western men and disavows the agency of non-white Eastern Others. Porter highlights the triumph of Western civilization over the wilderness. "Our next travelling was done in carriages, passing many plantations, sugar factorys [sic], large tracts of rice fields, and peanuts, (where a large business is done in manufacturing oil from peanuts) we, also, saw extensive patches of sweet potatoes."4

Paradoxically, while Porter constructs racial hierarchies as a means of establishing cultural difference between the white drillers and the native Others, his narrative is one of appropriation where he dominates by gathering the colonized into "civilization." In the latter part of his letter, Porter describes their quarters in Tjibodus. "Our bamboo houses are comfortable, and servants - two men and a woman - at $10 \mathrm{cts}$ a day each." There are, however, underlying tensions evident in Porter's rhetoric of appropriation and domestication. "We could fare very well, if our meals were cooked right, that is, such as in our own country," he complained. ${ }^{5}$

I will explain in this essay how Enniskillen township's "foreign drillers," both as British subjects of the settler colony of Canada and agents of imperialism, went about constructing a coherent representation out of the new realities they confronted while working in the colonial oil fields. I draw on a variety of post-colonial theories, histories, and works in literary criticism to illuminate the "peculiarities of the Canadians," and to explicate how they went about reinforcing the project of European capitalist imperialism while simultaneously disavowing the agency of non-white native Others. Second, I examine this group of workers as bearers of class, genider, and racial privilege in the oil fields where they were sent to work. For a significant proportion of Enniskillen's "foreign drillers," working for a large international oil company provided them with the opportunity to secure supervisory and management-level jobs and a position of class privilege while living abroad. This no doubt would have eluded them had they spent their entire lives working at home in the local oil industry. Enniskillen's "foreign drillers" became part of an im-

${ }^{3}$ Petrolia Advertiser, 18 October 1874.

${ }^{4}$ Petrolia Advertiser, 18 October 1874.

5etrolia Advertiser, 18 October 1874 . Although "a good show of oil" was reported initially by the drilling crew who went to Tjibodus in 1873, the yield proved too small to be commercially viable, and the search for oil was abandoned owing to a lack of capital. Canadian drillers from Enniskillen township would, however, return to the Dutch East Indies later in the 1890s. See Ooi Jin Bee, The Petroleum Resources of Indonesia (Kuala Lumpur 1982), 2. 
perial "overclass" by virtue of their "whiteness," "Britishness," and technical expertise in the mining and refining of petroleum. Third, this essay contributes to the more recent body of historical literature on imperialism, which seeks to break down the boundaries between "Empire" and "colony" and "home" and "away." The colonial oil fields became a space for the re-invention of Victorian ideals of domesticity. The connections between the imperial economy and the local Enniskillen economy and the process of class formation are explicated in the essay. The wives of Enniskillen's "foreign drillers," who both maintained households in their husbands' absences and sometimes joined them abroad, particularly after World War I, are also discussed.

In a 1924 Maclean's article commemorating the golden jubilee of foreign drilling, Victor Lauriston, a journalist and local Lambton County amateur historian, dubbed Petrolia "The Town of World Travelers." According to Lauriston, 134 drillers from Enniskillen township went on exploration and drilling expeditions to "foreign fields" between 1873 and the outbreak of World War I. Many of them went abroad more than once. A little-known aspect of Canadian history is that the "foreign drillers" from Lambton County, many of them from the town of Petrolia and the village of Oil Springs, provided the skilled labour and technical expertise necessary for the development of the global oil industry. The vagaries of the local oil market and the depletion of the oil resources in Enniskillen township by the late 1890 s forced many skilled oil drillers to seek employment in "foreign fields." In an era when only the wealthy, soldiers, and diplomats travelled abroad extensively, Enniskillen drillers travelled to the oil-rich fields of Java, Borneo, Sumatra, Persia, Galicia, Germany, India, Newfoundland, Russia, Italy, the West Indies, and the United States. Virtually anywhere in the world where oil was discovered Enniskillen's drillers provided the skilled labour and technical expertise.

In the latter half of the 19th century petroleum was used primarily for producing oil. It was also used in the manufacture of benzine, gasoline, kerosene, paraffin wax, asphalt, and lubricating oil. Petroleum lubricants greased the machinery that powered the industrial revolution. The demand for crude oil increased significantly in the early 20th century, particularly with the introduction of the automobile as a means of mass transportation. The exploitation of resources fueled European imperialism. At the turn of the century virtually all of Britain's oil came from the USA and Russia, with smaller amounts coming from the Dutch East Indies and Roumania. All of these countries were outside Britain's control. At the outbreak of World War I in 1914, the world's largest oil concerns were of American, Russian, and Dutch nationality. One of the British Admiralty's primary concerns was to secure an adequate supply of fuel for the Navy, and the British Government framed an oil policy to win control over the oil supplies in the Middle East. ${ }^{7}$ Beginning in the

\footnotetext{
${ }^{6}$ Victor Lauriston, "The Town of World Travelers," 19.

${ }^{7}$ Marian Kent, Oil and Empire: British Policy and Mesopotamian Oil 1900-1920 New York 1978); Louis Fischer, Oil Imperialism: The International Struggle for Petroleum (Westport,
} 
early 1870s drillers from Enniskillen township journeyed to these remote areas bringing their technical knowledge of "the Canadian drilling system," along with the components of the drilling rigs themselves, which were often manufactured locally at the Oil Well Supply Company.

I am indebted to writings of post-colonial scholars of the English-speaking world, many of them literary scholars, who have attempted to understand the history of imperial meaning-making. Edward Said's path-breaking study, Orientalism, with is central premise that, "European culture gained in strength and identity by settling itself off against the Orient," has influenced my analysis of the writings of Enniskillen's "foreign drillers." A reading of scholarly works focusing on travel writing, and the relationship between travel and the creation of racial and gender hierarchies, allowed me to identify the colonizing gestures in language. Rather than reading colonial texts as expressions of traditionally Western ideals, post-colonial literary critics read these literary texts as evidence of the manner in which such ideals have served in the historical process of colonization. The construction of hierarchies of racial and gender difference have also been central to this project. ${ }^{9}$

Post-colonial theorists have also argued for a re-examination of colonialism, beyond a simple analysis of machines of imperial power exercised from European metropoles, to incorporate the interactive social dimensions of colonization that took place in the colonies of exploitation. In her study of European travel writing, Mary Pratt foregrounds the interactive dimensions of colonial encounters with an emphasis on how subjects are constituted in and by their relations to one another using the idea of the "contact zone." The "contact zone," Pratt writes, refers "to the space of colonial encounters, the space in which peoples geographically and historically separated come into contact with each other and establish ongoing relations, usually involving conditions of coercion, and radical inequality, and intractable conflict."10 Thus, the "contact zone" provides a useful way for analyzing how

Connecticut 1926); R.W. Ferrier, The History of the British Petroleum Company, Volume 1: The Developing Years 1901-1932 (Cambridge 1982).

${ }^{8}$ Edward W. Said, Orientalism (New York 1979), 3.

${ }^{9}$ Mary Louise Pratt, Imperial Eyes; David Spurt, The Rhetoric of Empire: Colonial Discourse in Journalism, Travel Writing, and Imperial Administration (Durham and London 1993); Catherine Hall, "Going-a-Trolloping: Imperial Man Travels the Empire," in Clare Midgely, ed., Gender and Imperialism (Manchester and New York 1998), 180-99; Karen Dubinsky, The Second Greatest Disappointment: Honeymooning and Tourism at Niagara Falls (Toronto and New Brunswick, New Jersey 1999); Karen Dubinsky, "Local Colour: The spectacle of race at Niagara Falls," in Antoinette Burton, ed., Gender, Sexuality and Colonial Modernities (London 1999), 67-79; Ann Laura Stoler, "Rethinking Colonial Categories: European Communities and the Boundaries of Rule, Comparative Studies in Society and History, 13 (1989), 134-61.

${ }^{10}$ Pratt, Imperial Eyes, 4-7. 
Enniskillen's "foreign drillers" went about constructing the domestic subject of European imperialism as colonizers in the colonies of oil resource exploitation.

My approach differs from post-colonial literary scholars who have tended to rely either on published guidebooks or imaginative literature for their primary sources. I have gathered the letters written by Enniskillen's "foreign drillers" which were published in the two local newspapers, the Petrolia Advertiser and the Petrolea Topic, later merged as the Petrolia Advertiser-Fopic, during the heyday of "foreign drilling" between 1874 and 1930." The letters were sometimes addressed to friends or family members, but more often were in the form of letters to the editors of the two weekly newspapers. In November 1897, Richard Herring, editor of the Petrolia Advertiser, issued a call for letters from subscribers living in foreign countries. "We would take it as a favor," Herring wrote, "if they will write to this paper, briefly stating their impressions of their present places of residence, and also give our readers an idea of how those places compare with their old town, Petrolia." "We are confident," Herring continued, "that the letters we will receive will be well worth reading and will verify the statement that "nobody who ever lived in Petrolia failed to return."'12 The travel letter was perhaps the simplest form of travel chronicle and appeared widely in 19th-century North American newspapers.

Travel writing gave Enniskillen's "foreign drillers" the opportunity to produce themselves as authorities on travel to distant lands and other topics of general interest to their homebound neighbours in small-town rural Ontario. The travel chronicle, as William Stowe explains, testifies to a privileged experience and constitutes an authoritative voice. ${ }^{13}$ Enniskillen's "foreign drillers" were empowered by the experience of travel and travel writing, and had a coveted role in the local community. They had high-paying jobs in comparison to men who remained at home and they had the opportunity to travel abroad, which allowed them to claim respected cultural roles in the community. The letters composed by Enniskillen drillers working abroad can be distinguished from fiction by the expectation of their grounding in historical actuality. Despite this quite conventional expectation, the use of symbols, myths, metaphors, and other rhetorical strategies more often associated with fiction than travel writing were used to establish the connections between home, nation, and empire and to establish hierarchies of race, class, and gender power. The letters were a kind of conversation - albeit one-sided - where the relationship between colonzier and colonized was one of "co-presence, interaction, inter-

\footnotetext{
"There is a long-standing debate among local historians concerning the correct spelling of the name of the town. Patrick Barclay, the first postmaster, reportedly named the town "Petrolea" in 1863 . When the village was incorporated as a town in 1873, the spelling used was "Petrolia." Many residents continued to use the old spelling, hence the two spellings.

${ }^{12}$ Petrolia Advertiser, 18 November 1897.

${ }^{13}$ William W. Stowe, Going Abroad: European Travel in Nineteenth-Century American Culture (Princeton 1994), 55-73.
} 
locking understandings and practices." ${ }^{14}$ In addition a few extant memoirs, a diary, and personal family letters were located. They were used alongside the drillers' travel letters for purposes of identifying and mapping the basic tropes of colonial discourses.

Recent rethinking of imperial histories and efforts to integrate imperial history with British domestic history have benefitted from interdisciplinary exchanges. "Until recently," Antoinette Burton remarks, "the rule of thumb in British history has been to map a set of quite differently imaged communities: 'home' on the one hand and 'empire' on the other." Home and empire have traditionally been constituted as separate and distinct spheres, with home being the source of Britishness, progress, and civilization, and Empire as the other side of the world, the "dark continent," the as-of-yet undomesticated space of cultural backwardness. ${ }^{15}$ The so-called new British historians have instead suggested that the relationship between "home" and "Empire" was dialectic rather than dichotomous. Historians such as Antoinette Burton, John Mackenzie, Laura Tabili, Anne McClintock, Catherine Hall, and others, have illustrated that Empire was an integral part of British social, political, and cultural history. "Domestic" British culture was throughly influenced by imperialist ideas, and with it the meaning of racial difference. ${ }^{16}$ In Canadian historical writing, Carl Berger has argued that in English Canada, between Confederation and the outbreak of World War I, it was possible to be both a nationalist and an imperialist. ${ }^{17}$ More recently, Phillip Buckner in his 1993 Presidential Address to the Canadian Historical Association, stated that, "Canadian historians locked themselves into a teleological framework which is obsessed with the evolution of Canadian autonomy and the construction of a Canadian national identity and thus downplayed the significance of the imperial experience in shaping the identity of nineteenth-century British Canadians." In taking up Buckner's call "to put the imperial experience back where it belongs at the centre of 19th-century

${ }^{14}$ Pratt, Imperial Eyes. I am also indebted to Karen Dubinsky's discussion of travel writing and tourism in Burton, ed., Gender, Sexuality and Colonial Modernities, 67-79.

${ }^{15}$ Antoinette Burton, "Rules of Thumb: British history and 'imperial culture' in nineteenth-and twentieth-century Britain," Women's History Review, 3 (1994), 483-500.

${ }^{16}$ Anne McClintock, Imperial Leather: Race, Gender and Sexuality in the Colonial Contest (New York and London 1995); Antoinette Burton, "Recapturing Jane Eyre: Reflections on Historicizing the Colonial Encounter in Victorian Britain, Radical History Review, 64 (1996), 58-72. Shula Marks, "History, the Nation and Empire: Sniping from the Periphery," History Workshop Journal, 29 (Spring 1990), 111 -19; John M. Mackenzie, ed., Imperialism and Popular Culture (Manchester 1986); Laura Tabili, "We Ask for British Justice": Workers and Racial Difference in Late Imperial Britain (Ithaca and London 1994); Catherine Hall, "Rethinking Imperial Histories: The Reform Act of 1867," New Lefi Review, 208 (November/December 1994), 3-29; Antoinette Burton, "Who Needs the Nation? Interrogating 'British' History," Journal of Historical Sociology, 10 (September 1997), 228-9.

${ }^{17}$ Carl Berger, The Sense of Power: Studies in the Ideas of Canadian Imperialism 1867-1914 (Toronto 1970). 
Canadian history," I consider how ideas of nation and Empire were articulated in the writings of Enniskillen's "foreign drillers," and how the connections between "home" and "away," and "nation" and "empire," were shaped in Enniskillen township. ${ }^{18}$ Ultimately I argue for an appreciation of the peculiarities of the Canadian drillers both as British subjects of a white settler colony and as colonizers in the colonies of oil exploitation.

\section{Enniskillen Township's "Foreign Drillers"}

The movement of Canadian drillers to "foreign fields" received its greatest impetus in the 1880 s from the enterprise of Petrolian, William Henry McGarvey. McGarvey was born in Huntingdon, Quebec on 27 November 1843. In 1857 the McGarvey family moved to Wyoming, located approximately seven miles to the north of Petrolia. William McGarvey relocated to Petrolia in 1861, where he opened a general store known as "The Mammoth Store." Following the incorporation of Petrolia as a village on 13 December 1866, McGarvey, who was only 24 years of age at the time, became the first Reeve. He held the position until 5 March 1867. Later, in 1876, he was elected Mayor, and in 1879 he became Warden of the County of Lambton. A staunch Conservative in politics, McGarvey headed a Federal Royal Commission to survey the mineral resources of the North-West in 1880. The following year he was appointed manager of the Continental Oil Company where he became acquainted with J.S. Berheigm, an English oil operator. In partnership with Berheigm, McGarvey drilled for oil in the German province of Hanover. This venture was unsuccessful, and in $1882 \mathrm{McGarvey}$ and Berheigm proceeded to Galicia and Roumania. McGarvey introduced the Canadian system of drilling in the oil fields in Galicia. ${ }^{19}$

The Canadian drilling system, also known as pole tool drilling, was perfected in the oil fields of Enniskillen township during the oil boom days in Petrolia in the late 1860s. The surface or "flowing wells" were soon spent after oil speculators began extracting the oil resources in the region. A new science and trade in oil drilling emerged to meet the need to drill deeper into the rock for oil. The method of sinking the early oil wells in Enniskillen township in the 1850s was to dig and crib a four-foot shaft down to rock, then sink the well through the rock by driving the drill into the ground. These first wells were "kicked down" by manpower using spring

${ }^{18}$ Phillip Buckner, "Whatever happened to the British Empire?" Journal of the Canadian Historical Association, New Series, Vol. 4 (1993), 3-4. Colin Coates suggested that the "limited identities" approach to the writing of Canadian history has done little to address the significance of the majority identities including the experience of flow of British immigrants to Canada from 1867 to 1914 whose experience was shaped by the Canada-British connection. See Colin M. Coates, ed., Imperial Canada, 1967-1916 (Edinburgh 1997).

${ }^{19}$ Victor Lauriston, Lambton's Hundred Years 1849-1949 (Samia 1949), 188-9; Petroleum World (May 1922), 206; Dianne Newell, Technology on the Frontier: Mining in Old Ontario (Vancouver 1986), 128. 
poles. This method was soon replaced by steam-powered drilling rigs, known as the Canadian rig. A bit or cutting tool in the form of a chisel screwed to an auger stem was connected to jars or slips, which permitted a delayed power motion on both the upward and downward strokes. Unlike the American, or standard, system of drilling where the tools were suspended from a wire cable, in the Canadian drilling system, a series of wood tubes or wrought-iron casings were screwed together end-to-end to carry the string of tools. The rig ran the casing into the ground using a series of belts and pulleys powered by a portable steam engine driving a band wheel. The advantage of using poles was that they could hold drilling tools together better than a rope or cable while boring through rock. At first black ash from the forests of Enniskillen township was used to construct the rods. This drilling technique was ideally suited to the wet clay soils in Enniskillen township where it was not necessary to bore to deep levels to find oil, and where iron and steel were scarce and costly commodities. ${ }^{20}$

The partnership of McGarvey and Berheigm brought in the first successful well at Waglowka in Western Galicia, then part of the Austro-Hungarian Empire, sometime in the early $1880 \mathrm{~s}$. By 1887 , they were in a position to begin the construction of a refinery at Miariampole. In 1895, McGarvey and Berheigm reorganized their company as a limited trust company named Galizische-Karpathen Petroleum Aktien-Gesellschaft. McGarvey and Berheigm also built a drilling tool factory. At the beginning of the 20th century the businesses at Miariampole, which at that point were under the direction of McGarvey's eldest son Fred, employed more than 1,200 workmen. ${ }^{21}$ The oil fields in Galicia were among the largest in the world. McGarvey became a multi-millionaire before the outbreak of World War I forced the closure of his wells. Before the war, McGarvey and his wife entertained members of the European aristocracy in their apartments in Vienna. On 12 November 1895, his daughter, Mary Helena, married Count Von Zeppelin, a nephew of the inventor of the airship of the same name. An account of the lavish wedding was carried in the Petrolia Advertiser. 22

By the latter part of the 19th century Enniskillen township's skilled oil drillers were in high demand in "foreign fields." The Petrolea Topic reported in September 1889, that while English capital had been advantageously invested in Galicia, the drilling there had been done largely by Canadians. ${ }^{23}$ By the end of the 1880 s crews of Enniskillen drillers were at work not only in Galicia, but also in Roumania, Italy,

${ }^{20}$ Wanda Pratt and Phil Morningstar, Early Development of Oil Technology (Petrolia 1987), 3-9; Newell, Technology on the Frontier, 34-5; Petroleum World (June 1917), 247-8.

${ }^{21}$ Petrolea Topic, 6 January 1903; Charles Whipp and Edward Phelps, Petrolia, 1866-1966 (Petrolia 1966), 64; Belden's Illustrated Historical Atlas of the County of Lambton (Toronto 1880), 33.

${ }^{22}$ Petrolia Advertiser, 19 December 1895. A brief biography of Countess Zeppelin was published in the Petrolea Topic, 10 March 1915.

${ }^{23}$ Petrolea Topic, 27 September 1889 
Russia, India, Burmah, Sumatra, Bomeo, Mexico, and Australia. In 1888, John Henry Fairbank, pioneer oil operator, hardware merchant, banker, and politician testified before the Royal Commission on the Mineral Resources in Ontario that: "[t]he cause of the demand is, that they have superior tools and possess superior intelligence." "The men are largely the sons of settlers and people who drifted into the oil business," Fairbank stated. "The work is very hard, and requires a strong frame and a clear head. Our men become great experts at it. When they go abroad they get good wages, and expenses paid.".24

Enniskillen's "foreign drillers" learned their trade locally. For instance, W.O. "Bill" Gillespie was born in Petrolia on 15 Feburary 1878. His father looked after the oil properties of a weal thy USA oil speculator, a lawyer by the name of Griffiths. In 1886 Gillespie's father had an accident. When he was finally able to resume working young Bill would help him around the wells: "get his wood for the day, put it into the engine house in front of the boiler for him so he could get along till four o'clock." After he was dismissed from school for the day, Bill would take over from his father until he shut down the rig at six o'clock. Griffiths eventually went bankrupt and left Petrolia. Gillespie's father then went into a short-lived contract drilling business with another local driller, Charlie Slack, before starting a surface and cartage boring business. The business was apparently successful. Tragically, the senior Gillespie was killed on 17 July 1893, while boring clay on a drilling rig located in the east end of Petrolia. Bill Gillespie, who was only fifteen years of age at the time, took over his father's business temporarily. In June 1894, Bill went to work on Peter Slack's drilling rig. Charlie Keck was the driller on the rig, and Neil McGill was the engine man. Gillespie spent more than three years learning how to drill from Keck. He was paid a wage of ten dollars per well. Gillespie's career as a "foreign driller" began in 1903, when he was hired to go to Cuba to put down water wells. He made another trip to Cuba the following year, and then spent three years boring for the International Boring Company in Queensland, Australia. Before retiring from foreign drilling in 1926, Bill Gillespie drilled in central Africa, Upper Burmah, Sumatra, and Bomeo. ${ }^{25}$

Victor Lauriston noted that the manly characteristics of "hazard" and "muscle sense" acquired by a Canadian driller, born and bred around the drilling rigs of Enniskillen township made him a superior driller, in contrast to the Englishman who was unwilling "to take his coat off." "His work compels him to be a grimy mechanic," Lauriston wrote. "Wash that grimy mechanic, put him in evening dress,

\footnotetext{
${ }^{24}$ Report of the Royal Commission on the Mineral Resources of Ontario and Measures for their Development (Toronto 1890), 160-1.

${ }^{25}$ Much of the information about Gillespie's early years was gleaned from his personal memoirs recorded by his daughter Kathleen Gillespie when her father was over ninety years of age. My thanks to Kathleen Gillespie for sharing this document with me. See also Victor Lauriston, "Romantic Career of 'Bill' Gillespie," The Rig and Reel Magazine (October 1927), 3-14.
} 


\section{LABOUR/LE TRAVAIL}

and you have - in nine cases out of ten - as fine a gentleman as Canada, or England for that matter, could wish." "He has to be a thorough-going man to qualify as a driller," Lauriston continued. "If by any chance a moral or physical weakling crept into the ranks, the trade would inevitable make a man of him, either that, or it would kill him. ${ }^{, 26}$ In his article Lauriston associates the masculine character traits imbued in drillers trained in the oil fields of Enniskillen township with the burgeoning English Canadian nationalist sentiment of the post-World War I years, and the ongoing questioning of Canada's colonial relationship with Britain.

The capriciousness of the Canadian oil industry meant that during periods when the markets slumped local drillers were often unemployed. The first crew of foreign drillers who left Petrolia in 1873 did so in the midst of the depression that plagued the country for much of the decade, and into the next. During this period attempts were made by both local oil producers and refiners to agree on prices. Cartels were formed that nearly always collapsed. In 1898, John D. Rockefeller's Standard Oil Company gained control of Imperial Oil and transferred the refinery to the port community of Sarnia on the St. Clair River. This was a significant blow to the Petrolia economy, which was augmented a decade later when the Enniskillen oil fields began to dry up. ${ }^{27}$ Some drillers found work in other local industries, but the spectre of adventure for young men raised in rural Ontario, together with their highly specialized skills in oil drilling and the prospects of high wages, led many drillers to "foreign fields." The local newspapers were filled with announcements of the arrivals and departures of drillers and their families. By-lines such as "Left For Borneo, "Leaving for India," "Among the Drillers," "Petrolia 'Jerking' Austria," and "Home from Venezuela" appeared weekly and kept the community informed of the comings and goings of local drillers. According to Lauriston, the "lure of the bit and sinker" was too strong for Enniskillen's drillers, and they would no sooner return home before signing another contract to drill abroad. ${ }^{28}$

\section{The Travel Writings of Enniskillen Township's Foreign Drillers}

A lengthy narrative of their journey to the colonial oil fields was included in the travel writings dispatched home by several of the "foreign drillers." Their letters highlighted the boundaries between civilized, technologically advanced Western culture and the primitive, savage wilderness of the Eastern colonies. For the drillers who went to India and the East Indies, the joumey by steamship took almost two months. The drillers had to cross the Atlantic Ocean, proceed through the Mediterranean Sea, pass through the Suez Canal and the Red Sea, and cross the Indian

\footnotetext{
${ }^{26}$ Lauriston, "The Town of World Travelers," 19.

${ }^{27}$ Charles Whipp and Edward Phelps, Petrolia 1866-1966 (Petrolia 1966); Gary May, Hard Oiler!: The Story of Early Canadians' Quest for Oil at Home and Abroad (Toronto 1998), 114-17.

${ }^{28}$ Lauriston, "The Town of World Travelers," 19
} 
Ocean. They usually spent a few days in London where they finalized the terms of employment with the British agents of oil companies and had a complete physical examination. ${ }^{29}$ The drillers used the visit as an opportunity for some sightseeing. The tourist gaze of the Enniskillen drillers was constructed around the symbols and signs of 19th-century British imperialism. They visited Trafalgar Square, Westminister Abbey, and the Houses of Parliament. They set their watches to Big Ben, and toured the Tower of London where they saw the Crown jewels, among them those of Queen Victoria. Madam Jarley's Wax Works and the British Arsenal were favourite attractions with the drillers. In his letter to the editor of the Petrolia Advertiser, James Rowe reported that the wax works were "very attractive, for there we find represented in wax the royal family and other persons of honor and high standing throughout the world." British imperialist discourse was incorporated into the narrative. Rowe reported that, "The most pathetic figures were the Queen Regent of Spain and her son, near them was President McKinley, and he seemed embarrassed in the presence of the beautiful queen." At the British Arsenal, where "one must prove himself a British subject before gaining admission," Rowe saw "all the latest improved implements of war, as well as every conceivable old kind." In London they were reunited with two more "Petrolia boys," and gave them a hearty welcome. With an expression of nationalist imperialist sentiment Rowe concluded his letter: "When journeying in these old lands we cannot forget the new land, and often feel like singing 'The Maple Leaf Forever." 30

The long journey eastward, most of it over open seas, was usually presented in the drillers' travel writings as leisurely and uneventful. Port Said, at the entrance of the Suez Canal was the first exposure to non-European culture for Enniskillen drillers who ventured to the Orient. In the fall of 1879 , R.A. Townsend was contracted by the British-owned Barangah Oil Refining Company to superintend the drilling of wells on the Barangah Islands located approximately $\mathbf{4 0 0}$ miles from Calcutta. Townsend was raised in Brant County. He went into the oil business with Melville Parker of Peel County during the oil boom in Enniskillen township in the late

${ }^{29}$ Many of the extant travel writings were penned by Enniskillen drillers who went to the East Indies. In 1880, A.J. Zijlker, Dutch manager of the East Sumatra Tobacco Company, discovered oil pools in the vicinity of his plantation. He secured a concession to the oil lands, officially named Telaga Said, from the Sultan of Langkat. The discovery of oil in commercial quantities at Telaga Said provided the impetus for exploration and drilling in Sumatra, North Borneo, Brunei, Sarawak, and Java. In 1890, Zijlker signed over his petroleum concessions to the newly formed Royal Dutch Company. Some of the drillers who went to the Dutch East Indies in the 1890s and early 1900s signed with the Shell Transport and Trading Company founded by an Englishman, Marcus Samuel. Financial difficulties forced the merger of the Shell Transport and Trading Company with Royal Dutch Shell in 1907. See Bee, The Petroleum Resources of Indonesia, 2-3; Petrolia Advertiser, 3 September 1896; Petroleum World, 21 October 1905; April 1921.

${ }^{30}$ Petrolia Advertiser, 18 January 1899; 4 October 1899; Petrolea Topic, 13 April 1899. 
$1860 \mathrm{~s}^{31}$ Two other experienced drillers who also leamed the trade locally in the Enniskillen oil fields, J.C. Crosbie and William C. Bell, accompanied Townsend on the journey to the Far East. On 8 January 1880 Townsend wrote a lengthy letter to the editor of the Petrolia Advertiser, which was published in the newspaper in two parts. ${ }^{32}$ Writing from the vantage point of his hotel room, he surveyed the landscape "fanned by the pure breezes from over the coffee gardens of Mocha," and remarked, "I ought to feel happy if I am not." He further disclosed to his readers that for him, "This is fact and fancy wedded, at least this is the realization of years of dreaming, and unlike the average dream, the fact excels fancy." ${ }^{33}$ The Orient as a visionary imagination was, as Edward Said argued, integral to the Western style of "dominating, restructuring, and having authority over the Orient."

Post-colonial literary scholars have suggested that the Orient as a visionary imagination was also dependent upon a fantasy of seduction and eroticization in which the colonies are represented as "the harems of the West." Townsend writes that as he prowled the deck of the ship, about to experience "the dim uncertainties" of Eastern life for the first time he happened upon what he believed to be two Eastern women "with turbaned heads and loose flowing robes." He describes the encounter as he approaches them to make his "salaams":

With stately bearing, I approach, and with dignity and grace I touch my head, my breast and my lips - signifying that with my head I respect, with my heart I love, and with my lips I praise you. I saw at once I had made an impression, and I confidently awaited the result. It came. One of these beauties in arising, exposed about six feet of the best combination menagerie it has ever been my privilege to witness, consisting of snake skins, as malice, flees [sic], rags, gray backs, jaws, and the spicy odor peculiar to these people and this land, and addressed me in Arabic beginning with the work "Allah" and ending with "backsheesh," all of which being interpreted meaneth, Thou son of a Christian dog, your diabolical intentions are anticipated, know then that we are the sons of the Great Prophet, and are the police of yonder

${ }^{31}$ In August 1895, the Petrolia Advertiser printed an excerpt from the Detroit Tribute describing Townsend's visit to the city. According to the account, Townsend, during a residence of thirteen years in India, had accumulated a considerable fortune and he had organized the East India Mining Company with capital of three million pounds sterling. While en route to the Russian oil fields in the fall of 1898 , he became ill and was forced to return to London, England, where he died on 10 October. See Petrolia Advertiser, 1 August 1895; 19 October 1898.

${ }^{32}$ Petrolia Advertiser, 3 December 1880; 10 December 1880.

${ }^{33}$ Petrolia Advertiser, 3 December 1880.

${ }^{34}$ Said, Orientalism, 3, 41. Said suggested that the Suez Canal destroyed the Orient's distance, "its cloistered intimacy" away from the West. According to Said, the Orient was transformed from resistant hostility into obliging and submissive partnership. Townsend's gaze points to Western domination, but there is still evidence of resistance from Arab peoples in his narrative. 
city semt on board to look after your health, and test your viscera by contact with opthalmia [sic], small pox, cholera, leprousy [sic], \&c., and a rupee only will appease us.

The intimation of cross-dressing and disguise leads to a questioning of the masculinity of the Eastern men. "I paid the rupee," Townsend continued, "but was surprised by all this from his rank and smell." ${ }^{35}$ The Orient in the driller's narrative vacillates between eroticization of the East and the symbolic constnuction of the Orient in terms of sexual danger. Townsend both delights in and fears Eastern culture. For 19th-century Western men, the Orient was something that had to be contained and controlled.

This erotically charged language marks the entrance of the colonizer. In this rhetorical strategy, cultural critic David Spurr suggests differences in power are reformulated as gender difference and an entire people is allegorized by the figure of the female body. ${ }^{36}$ The image of woman's sexual degeneration was used to invent hierarchical distinctions among the races and confer power among white men. In October 1897 Edward Winnett of Oil Springs left for Sumatra to assist in the construction and operation of an oil refinery. Edward and his wife Annie moved to Oil Springs from London, Ontario in 1883. From 1885, until he left for Sumatra on 7 October 1897, Winnett operated a small boiler shop owned by his father in the village. ${ }^{37}$ Winnett, who spent one year in Sumatra, recorded his perceptions of the experience in a diary. On November 22, the steamer Prince Hendrick docked in Port Said. "The first thing that caught my eye was boat loads of Egyptians hundreds of them." Winnett wrote, "they are the worse looking lot of people I ever saw all bear [sic] naked with the exception of a filthy cloth tied around their loins and another tied on for a hat." After touring the city he concluded that, "there seems to be no civilisation there you can see." "In passing houses there you can see young girls winking and beckoning for one to come in." 38

In their travel writings, Enniskillen's "foreign drillers" represented Port Said as a site of sexual danger, filth, and debasement, which empowered white Western men as agents of civilization. They were obsessed with the bodies of Arab men and women and invested them with moral value. R.A. Townsend described the Arab peoples as "filthy," "ragged," and the most "accursed lot of the 'genus homo'." "Before embarking," Townsend wrote, "we glanced at the motley crowd on the quay, men, old, gray and wrinkled women, squatting tailor-like upon the sands, with each a basket balanced upon her head, and from beneath their eyes, covering nose and mouth, a yard or more of netted filth, the famous veil of the East." Erotic

\footnotetext{
${ }^{35}$ Petrolia Advertiser, 3 December 1880

${ }^{36}$ Spurr, The Rhetoric of Empire, 173-5.

${ }^{37}$ Gary May, Hard Oiler!: The Story of Early Canadians ' Quest for Oil at Home and Abroad (Toronto 1998), 177-78.

${ }^{38}$ Personal Diary of Edward Winnett, 22 November 1897, Oil Museum of Canada, Oil Springs, Ontario.
} 
fantasies surrounding the Arab women he encounters are interwoven with the trope of debasement and filth. In concluding his narrative about his visit to Port Said, Townsend comments that it is "without a regret that [he] bid adieu to this Sodom of the 19th century, this gateway of the east. ${ }^{39}$ Subsequent drillers from Enniskillen township gazed upon the city in a similar way. Another correspondent, "Old Benwell," who provided the editor of the Petrolia Advertiser with a narrative of his journey to Sumatra in the summer of 1898 , proclaimed Port Said, "the wickedest city on earth. ${ }^{40}$

As the ship carrying Townsend and the other two Enniskillen drillers made its way through the Suez Canal they passed a British troop ship. They exchange salutes "with the greatest flag." "I now think," Townsend reflected that, "I never before heard a cheer and I never before was so proud and thankful for the British blood I carry about with me, thin of course, but British still., ${ }^{41}$ Townsend's laudatory remarks about the British Empire were intended to justify imperialism. His statements suggest a more complex relationship than a simple empire/colony connection. As a colonial subject from one of Britain's white settler colonies, Townsend's British blood may have been "thin." Although he was actually a "colonial" himself, his white skin and connection with Britain as a British immigrant to Canada elevated him to a status above that of non-white natives in the colonies of oil exploitation. This suggests that the discourses of late 19th and early 20th-century colonialism are more complex than recent imperial scholarship or the writings of post-colonial theorists have implied. In the case of Enniskillen's "foreign drillers," the boundaries between colonizer and colonized were never simple or dichotomous. They were subjects of one of Britain's white settler colonies while at the same time they bolstered British imperialism in the colonies of oil exploitation where they disavowed the agency of native peoples.

Not only did the drillers' narratives conform to dominant Western constructions of sexuality, they also fixed their tourist gaze on landmarks associated with Bible stories, thus furthering the project of colonizing the landscape. "We were then in the Red Sea," wrote "Old Benwell" in the fall of 1898 following his arrival in Sumatra. "We saw the rock that Moses smote with his staff and brought forth water for the children of Israel, also where he led them through the Red Sea, and Mount Sinai, where the ten commandments were to the children of Israel. ${ }^{, 42}$ Oil Springs boiler maker Edward Winnett was the embodiment of what historian Lynne Marks describes as the "Christian gentleman" of late 19th-century small-town Protestant Ontario: a man for whom Christian religious beliefs and church involvement were

${ }^{39}$ Petrolia Advertiser, 10 December 1880.

${ }^{40}$ Petrolia Advertiser, 26 October 1898. In a similar vein M.J. Kelly wrote that Port Said was the "hardest place in the world," with the chief occupation being begging and peddling. See Petrolia Advertiser, 11 April 1900.

${ }^{41}$ Petrolia Advertiser, 10 December 1880.

${ }^{42}$ Petrolia Advertiser, 26 October 1898. 
closely linked to a commitment to family life. Winnett attended church services held on board ship as they made their way to Sumatra. As they crossed the Red Sea he wrote in his diary: "I can see where the Israelites crossed the Red Sea. It is something most wonderful to stand on the steamer and just think of such a large body of water rolling back and allowing the Israelites to pass over. ${ }^{, 43}$

Christianity and science clashed in R.A. Townsend's narrative. As they passed the location where the Israelites supposedly crossed the Red Sea, Townsend, who was given privileged access to the Captain's charts, noted that "there is a channel mid-sea a mile or two wide and 6 to 8 fathoms deep." "Query," Townsend asked, "if the children crossed here, did they have ladders with them, or were they expert at climbing?" Although Townsend doubted that any man could part the Red Sea, or that the "children of Israel" could scale its banks, his experiences as a traveller led him to retain his faith in a Christian God. "I needed not to leave the Laurentian rocks, nor the beautiful valley of the chains of lakes, nor heavens vaulted dome which covers the green fields, and broad acres of my beloved Canada, to teach me here, that their [sic] was and is a God," he wrote, "but since I have crossed many seas, since a new hemisphere, a new earth, has been passing beneath my gaze, like a panoramic ribbon, I have added lessons, and mine eyes have seen His glory in other forms. ${ }^{, 44}$

As the drillers approached their destinations their travel writings tended to take the form of boy's adventure stories, where the young heroes were fine exponents of British manliness and muscular Christianity. They must confront the unknown "wilderness" of the jungles of the Orient or face pirates on the Arabian Sea. This literary genre was no doubt familiar to a generation of young men raised on a steady diet of adventure stories published in The Boy's Own Paper, or versed in the poetry of Rudyard Kipling and Henry Newbolt. ${ }^{45}$ Challenge and response was part and parcel of the project of Empire-building.

The language of "wilderness" and the perils of the unknown in the drillers' narratives take on an originating authority and confer upon them power to represent themselves. It is up to the drillers to systematize and bring order to the wilderness. The drillers' adventure narratives further conferred upon them the status of con-

\footnotetext{
${ }^{43}$ Winnett diary, 23 November 1897; Lynne Marks, Revivals and Roller Rinks: Religion, Leisure, and Identity in Late-Nineteenth-Century Small-Town Ontario (Toronto 1996), 32-3.

${ }^{44}$ Petrolia Advertiser, 10 December 1880.

${ }^{45}$ The "wild North West" of Canada was also the scene of adventure stories published in The Boy's Own Paper. The heroes were nearly always of British background. See R.G. Moyles and Doug Owram, Imperial Dreams and Colonial Realities: British Views of Canada, 1880-1914 (Toronto 1988); J.S. Bratton, "Of England, Home and Duty: The Image of England in Victorian and Edwardian Juvenile Fiction," in John M. Mackenzie, ed., Imperialism and Popular Culture (Manchester 1986), 73-93; Fred Reid and David Washbrook, "Kipling, Kim and Imperialism," History Today, 32 (August 1982), 14-20.
} 
quering heroes among their friends and neighbours at home. On 1 March 1899 the Petrolia Advertiser published a letter from "A.B.C." under the heading "Some Adventures of the Boys." In his letter the correspondent describes the dangers encountered as the drillers made their way through the jungles of Sumatra. "When we left the launch it was a queer experience to be sailing up a small river in a small boat in the wilds of Sumatra, with nothing but woods on either side of you, and it so thick that the eye could not penetrate more than two or three yards, and in some places not so far." "The stream is very crooked," he continued, "and a boat ten yards ahead of you could be easily lost track of, but returning suddenly to view, only to be lost again in another turn either to the right or left." "A.B.C." pronounces the pattern of the growth of the trees alongside the river as "strange" in comparison to those at home. "There is no grass nor anything else but trees grows on the banks of the stream," he observes. "It is a strange sight to see, and what we would call the trunk or stump of the tree stands several feet from the ground, and the roots branch out on every side — big ugly claws. ${ }^{46}$

At the same time, the driller reinscribes the imperial social order with its hierarchy of racial privilege. "A.B.C." reveals that "Cooleys" transported their luggage and supplies up the river. Following their arrival at the drilling sight, the crew of Canadian drillers watch the natives work for a time. According to "A.B.C.," "they did not do very well because they did not understand the drilling business at that time," $" 47$ and they required the knowledge and expertise of the "civilized" Canadian drillers to develop the petroleum resources.

Confrontations with wildlife were integrated into the drillers' adventure stories. John Collins wrote about his encounter with a tiger roaming around the drillers' quarters in Kotei, East Borneo in May 1900:

I was awakened at 3:00 am this morning on hearing the dogs barking and although I tried to prevent them, I found to my surprise that a tiger was underneath the mess room. I immediately returned to my room and got my gun, and found the animal still crouching in the same position on my return. All I could distinguish were his eyes, as the morning was very dark and cloudy. So I fired in that direction, and the shot had the desired effect, as the tiger rolled over and died immediately. It measured six feet from tip to tip, and was three feet high, and was, I believe, a young animal in prime condition.

Collins further indicated that he hoped to have the skin cured, so that he might show his "trophy" to his friends when he returned to Petrolia. ${ }^{48}$ Other drillers provided readers back home with stories of their heroic encounters with poisonous snakes, some reportedly twenty-six feet long! $!^{49}$

${ }^{46}$ Petrolia Advertiser, 1 March 1899.

${ }^{47}$ Petrolia Advertiser, 1 March 1899.

${ }^{48}$ Petrolia Advertiser, 1 August 1900.

${ }^{49}$ Petrolia Advertiser, 1 March 1899; Petrolia Advertiser, 3 July 1880; Petrolia Topic, 1 July 1880. 
For the "foreign drillers" who journeyed to the East Indies and British Burmah in the late 19th-century the curios mailed home to Petrolia added to the "authenticity" of the drillers' narratives of adventure and contributed to the invention of imperial masculinity. In May 1880, R.A. Townsend sent the skin of a "very" poisonous snake to Richard Herring, editor of the Petrolia Advertiser. Accompanying the snake skin was a note informing Herring that the snake was of the "Tie Prolongi" species, and that this species found "it rare sport to chase a Christian at sight." Some of Townsend's men had apparently killed the snake on the roof of the cook house. Townsend concluded his letter with a postscript informing Herring that he need not be afraid to handle the snake skin, as it was not poisonous. ${ }^{50}$ Occasionally, the two local newspapers published lists of "curiosities" sent home to local citizens. Thus, the colonial adventure was consumed imaginatively when the drillers wrote their own scripts and literally when the drillers sent curios to friends and family back home.

Adventure narratives composed by Enniskillen's "foreign drillers" continued to appear in the local newspapers into the $1920 \mathrm{~s}$, although by this time travel abroad was becoming a regular occurrence for local drillers and their families. In May 1922, Oil Springs driller W.C. Parker wrote that they were attacked by pirates in the Arabian Sea as they made their way to Persia to drill for the Anglo-Persian Oil Company. The pirates, described by Parker as "dusky savages," appeared on the deck of the steamer "armed with axes, piles and swords or cutlasses similar to those used in the days of Drake and Nelson." Twenty-year-old Ernest Kells, who started working on the drilling rigs in Petrolia at the age of seventeen, is presented in the narrative as the masculine hero. "Kells being a cool headed, resourceful young man," Parker wrote, "calmly stooped and picked up a bar of 1 inch iron which lay handy, with which he attacked three of the pirates." Kells hit one of the three pirates, and the other two quickly retreated. By this time the crew of the steamer, 45 men in all, had arrived on deck, "armed with axes, belaying pins, cleavers, clinker bars and in fact everything movable that was on board. The pirates on seeing this array gave up the ghost and took to their boats."

The analysis of letters composed by Enniskillen township's "foreign drillers" suggests that as the drillers experienced non-European culture for the first time, they reproduced the familiar gestures of 19th-century fiction writers and colonial officials. They replicated rhetorical tropes of colonial discourse identified by post-colonial theorists and literary critics. Among the tropes identified in the narratives of the "foreign drillers" were: a visual mastery of the landscape from the writers' privileged point of view; an obsession with bodies, particularly the bodies of native women, accompanied with warnings about their seductive allure; appropriation of the territory by inclusion and domestication; classification and ordering of

${ }^{50}$ Petrolia Advertiser, 30 July 1880.

${ }^{51}$ Petrolia Advertiser-Topic, 20 June 1922. 
natural beings; idealization of the colonialist enterprise against the setting of emptiness and disorder; the notion of the "white man's burden" as a metaphor for the civilizing mission; and insubstantiation or seeing the Orient as a dream. ${ }^{52}$

\section{Encounters in the "Contact Zone" and the Re-invention of Domesticity}

During the 19th and early 20th centuries, the colonial oil fields became a theatre for the re-invention of European imperialist ideals of domesticity. The domestic/colonial and civilized/backward relationship was never entirely, or homogeneously, either "home" or "empire." Nevertheless, it is a testament to the power of a common racial heritage that the white "foreign drillers" from Enniskillen township became part of the imperial overclass. The drillers from Enniskillen township enjoyed a position of privilege while working abroad by virtue of their race, gender, and technical skills in the extraction of oil resources. In the colonial oil fields the processes of racialization, class formation, and the construction of gender difference were all mutually constitutive.

Enniskillen drillers usually signed contracts of one, three, or five years in duration. Bill Gillespie signed a standard employee contract with Messrs M. Samuel \& Co. of London, on behalf of the Nederlandsch Indische Industrie en Handel Maatschappu on 22 November 1904 for his services in Borneo. The company agreed to provide Gillespie with a second-class passage from Petrolia to Borneo. Gillespie was to work not less than eight hours per day once he arrived in Borneo. He was to be paid a rate of $\$ 5$ American per day, plus $\$ 25$ per month for the cost of food. Capitalist imperial authority was sanctioned using dominant middle-class ideals of morality and domesticity. The company reserved the right to stop the pay of any driller in the case of illness caused by "insobriety, immorality or other misconduct and to discharge the said employee summarily on any of these accounts." In the case of dismissal for behaviour deemed immoral by the company, the driller also forfeited his return passage to Petrolia and was legally bound to refund the cost of his passage from Petrolia to Borneo. ${ }^{53}$

A similar "morality clause" was included in the three-year contract signed by Ernest Kells on 1 March 1928 with The First Exploitation Company of England for his services in Persia. The contract also contained a clause that was tantamount to garnisheing the driller's wages. The Company was entitled to deduct monthly installments of five pounds from his wages and pay interest at the rate of five per cent per annum on the sum retained. This was called a "Retention Fund." In the event of a driller terminating his contract before eighteen months had passed, or if he was

${ }^{52}$ Pratt, Imperial Eyes, 15-35; 69-140; Spurr, The Rhetoric of Empire, Said, Orientalism, 5-7, 49-110.

${ }^{53}$ Contract between William Oliver Gillespie and the Nederlandsch Indische Industrie en Handel Maatschappu, 22 November 1904, Oil Museum of Canada, Oil Springs, Ontario. 


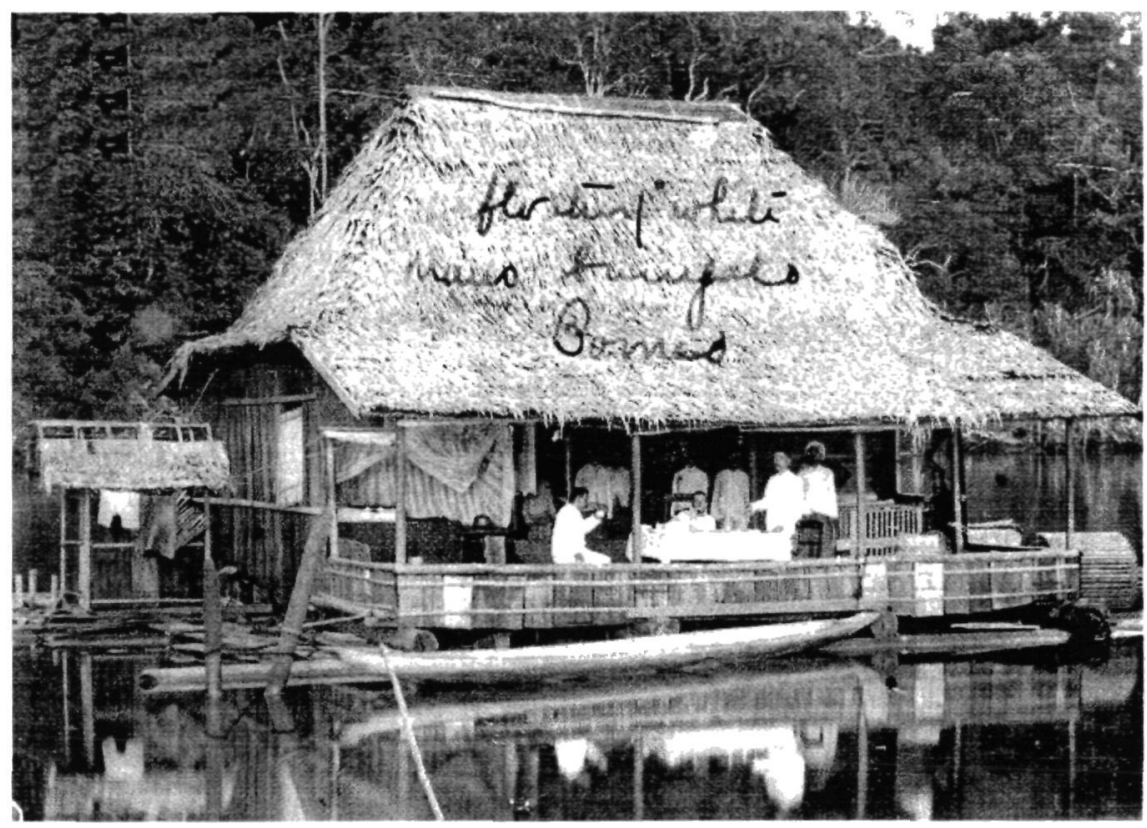

Figure 1. Enniskillen Drillers’ Bungalow in Miri, Borneo.

dismissed for insobriety or gross misconduct, the company was entitled to recoup its losses from the Retention Fund. ${ }^{54}$

The drillers' contracts also contained provisions for messing and servants. Gillespie's contract with M. Samuel \& Co. stipulated that the employer would provide unfurnished lodgings, water, and light and that "the said employee shall provide his own native servant and pay for his own washing the said employers providing suitable unfurnished lodgings for the said native servant." Thus class differences between the white drillers as masters and their native servants were racialized and given capitalist imperalist sanction in the contracts signed by Enniskillen drillers with the oil companies. The same provisions were written into another subsequent contract signed by Gillespie with the Anglo-Saxon Petroleum Company on 12 July 1920 whereby he agreed to go to Sarawak for three years. ${ }^{55}$ Similar provisions were probably included in the contract signed by Edward

${ }^{54}$ Agreement between The First Exploitation Company Ltd, England and Ernest Edward Kells, 1 March 1928, Oil Museum of Canada, Oil Springs, Ontario.

${ }^{55}$ Contract between William Oliver Gillespie and the Nederlandsch Indische Industrie en Handel Maatschappu, 22 November 1904; Contract between William Oliver Gillespie and The Anglo-Saxon Petroleum Co. Ltd., 12 July 1920, Oil Museum of Canada, Oil Springs, Ontario. 
Winnett when he went to Sumatra in the fall of 1897 . Winnett wrote in his diary on 16 December 1897, that he had purchased two wardrobes, two bedsteads, twelve chairs, a looking glass, mattresses, pillows, mosquito netting, and hanging lamps in Palambang. Upon returning to his bungalow the following day he found some natives fixing up the room and erecting a bathroom for the drillers. ${ }^{56}$

In his travel chronicle "A.B.C." presents a view of master-servant social relations in which Victorian constructions of domesticity are naturalized. He rounded out his narrative of adventure in the "wilds of Sumatra" with a detailed description of their housekeeping arrangements and the "civilizing" influences of the Enniskillen drillers. This discourse was part of the process by which European imperialist domestic ideals were introduced and white Anglo-Canadian drillers were made masters of the non-white "savages." A Chinese cook was secured from Berandon. An arrangement was made whereby the cook would live with the drillers. "We were to pay him so much a month," he wrote, "and he would have to furnish everything to eat, and that saved us a lot of trouble, for we had to send to Berandon for everything." ${ }^{27}$ The driller praised the native cook, indicating that he did very well despite that fact that he had no stove and only an open fire with which to prepare meals. The drillers also planted a vegetable garden. Tending the garden in Sumatra was probably the work of the native house servant.

The labour of non-white native Others was an important "civilizing" influence in colonial discourse, and another means by which class and racial differences were mutually constituted. During the year he spent in Sumatra, Edward Winnett supervised large crews of Chinese and Malay labourers hired to construct a pipeline and to unload metal boiler plate from steamships to be used in the construction of a new oil refinery. Conflicts sometimes occurred between the native workers and their white employers. On 12 September 1898 Winnett wrote:

This is a very busy morning all the Coolies having struck for more money all together there was 360 men on strike they were all collected around my Bungalow they were a dangerous looking lot nearly every one of them had a cleaver or what they call a prong with them and others with large knives in their belts so we had to give them a raise of pay instead of lowering their pay so before noon we had them all satisfied and back to work. ${ }^{58}$

In his text Winnett defines the native workers as unruly and dangerous, although it would appear that wage reductions were imminent and most likely prompted the strike.

Subsequent Enniskillen drillers categorized the native peoples of Borneo and Sumatra using racial hierarchies that linked skin colour and physical attributes with

\footnotetext{
${ }^{56}$ Winnett diary, 16-17 December 1897.

${ }^{57}$ Petrolia Advertiser, 1 March 1899.

${ }^{58}$ Winnett diary, 12 September 1898.
} 
moral characterizations and usefulness to the drillers in the oil fields. "There are many tribes of the human race in Borneo, but the wildest most isolated, and never seen by the ordinary travellers, and sometimes by people working a number of years in Borneo, are the Punans, Murits and Land Dayaks, or Dyaks," one Petrolia driller wrote. These peoples, the driller revealed, lived in the jungle and lived off wild fruit and the roots of bamboo, and the meat of snakes, monkeys, and wild pigs. He described the Punans as "a strong, healthy, well-knit looking lot, light in color in comparison with other native tribes, probably from living in the dark recesses of the jungle." The Land Dyaks who had been persecuted and hunted by the Sea Dyaks lived in the mountains. According to the driller, the Land Dyaks were the more civilized of Bomeo's native peoples. They were industrious and honest, and occupied villages of a permanent character. The Kengar, Kayans, and Sea Dyaks were elaborately tattooed from the hips to the knees. "The Kayans are supposed to be on a higher plane of civilization than the Sea Dyaks, though more cruel and their women are more inhumane than the men," the driller pointed out. The Kayans also had very light skin. The Sea Dyaks were head-hunters who used the heads for religious purposes. In his travel chronicle the driller indicated that the Sea Dyaks inhabited the coastline of the island and were employed by the different oil companies for clearing the jungle for surveyors and geologists. They were also used as watchmen in the oilfields. Although they appeared to be peaceful people, the driller noted that, "they had not lost the art of taking heads. ${ }^{, 60}$ Another driller writing two years earlier in 1923 , indicated that the Dyaks "are absolutely worthless as workers but are unexcelled as watchmen ... and when put on a job will stay 'put'." All the heavy work was done by Chinese labourers. ${ }^{61}$ This racial hierarchy further served to bolster the authority of the white drillers in the colonial oil fields.

The "foreign drillers" from Enniskillen township helped to create a new sense of "whiteness" in the colonial oil fields by constructing a hierarchy of racial difference that defined native peoples as non-white Others. ${ }^{62}$ The lighter skinned natives were always judged more useful to the white drillers. Dark-skinned natives were defined as "savages" who were untrustworthy and inhabited the jungles. Class formation and a systematic sense of whiteness developed hand in hand in the colonies of oil exploitation. The white drillers' technical skill and status of racial and class privilege afforded them positions of authority and prestige that eluded them at home. Bill Gillespie described for his neighbours back home how he, "just an ordi-

\footnotetext{
${ }^{59}$ See Petrolia Advertiser, 1 November 1899, 31 May 1899; Petrolia Advertiser-Topic, 22 July 1920; 19 October 1922.

${ }^{60}$ Petrolia Advertiser-Topic, 19 November 1925.

${ }^{61}$ Petrolia Advertiser-Topic, 27 December 1923.

${ }^{62} \mathrm{My}$ thinking here has been influenced by my reading of David Roediger's The Wages of Whiteness: Race and the Making of the American Working Class (London 1991).
} 


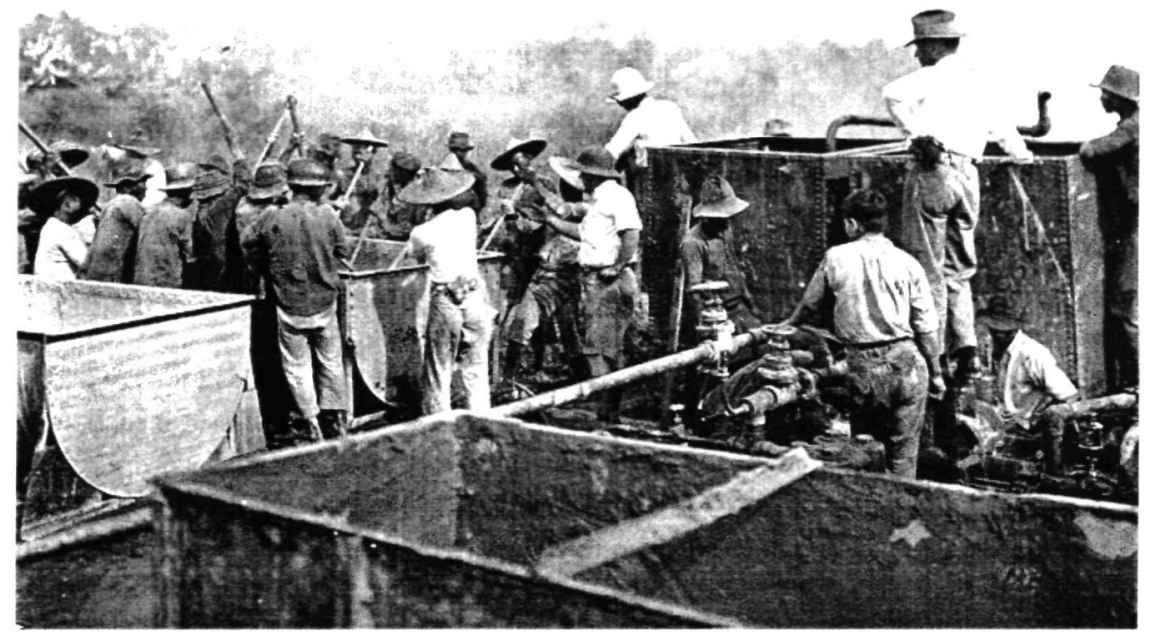

Figure 2. Cementing a Well in Miri.

nary driller," was given the privilege to meet the Prince of Wales in Brunei, Borneo in May $1922 .^{63}$

Enniskillen drillers by virtue of their technical expertise in oil drilling, and their developing sense of "Canadianness," defined themselves as more suited to the task of empire-building than Europeans. A few months after he started work in British Burmah in the spring of 1880 , John W. Crosbie penned a letter to John Clinton of Petrolia. In his letter Crosbie declared that the climate, "although disagreeable and frequently fatal to Englishmen, is not particularly hard on Canadians, as it resembles very much our July and August weather all the time." ${ }^{\circ 4}$ The Canadian drillers who went to British Burmah, and to the East Indies, supervised gangs of native labourers. The labour done by the "coolies," Crosbie reported, was not worth much, "one good Canadian being able to do more work than half a dozen of them." 65

Enniskillen drillers who went to the East Indies learned the Malayan language and made it their own. In December 1899, M.J. Kelly was able to report that "Baldy" Stokes "talks Malayan like a native." The "foreign drillers" learned native languages in order to communicate with gangs of native labourers under their su-

\footnotetext{
${ }^{63}$ Petrolia Advertiser-Topic, 12 July 1922.

${ }^{64}$ Petrolia Topic, 1 July 1880.

${ }^{65}$ Petrolia Topic.
} 
pervision. Robert Laid frequently lapsed into Malay when recalling his experiences in Borneo for the Toronto Star Weekly many years later. ${ }^{66}$

Sometimes, albeit rarely until after World War I, wives and children accompanied their husbands to the colonial oil fields. Although it is possible that at least a small minority of the "foreign drillers" had homosexual relationships, or sexual relationships with native women, these liaisons were not mentioned in the drillers' travel writings. In her study of the plantations of North Sumatra, Ann Laura Stoler found that plantation owners encouraged concubinage among native women and white overseers. ${ }^{67}$ There was, however, no evidence of such practices in the colonial oil fields of the Dutch East Indies.

Some of the drilling companies constructed exclusive "whites only" club houses for the amusement of their employees. "Old Benwell" went to the company club house shortly after his arrival in Berandan, Sumatra in the fall of 1898. The facility was equipped with a piano, billiard tables, bowling alley, and all manner of games. At some drilling sites, however, the drillers apparently had to devise their own amusements. In a letter to the editor of the Petrolia Topic, James McLean described a celebration organized by the "boys" to mark the completion of a new bungalow they had constructed. A band organized by the driller, and dubbed the "Sanga Sanga band," provided the entertainment. "We had dancing as well," McLean wrote, "but unfortunately it was only a 'stag dance' for the want of the fair sex, which loss was greatly felt through the evening." Commenting on the lack of opportunity for heterosexual contact with white European women in Sumatra, McLean remarked: "We should have given everything in our power to have had a few of our damsels to have graced the entertainment.

A handful of women did accompany their husbands to the East Indies before World War I. J.W. Crosbie's wife spent fifteen months with her husband in Sumatra, returning to Petrolia in the spring of $1896 .{ }^{69}$ In the early years of the 20th century, Robert Laird's wife accompanied her husband to Borneo. The Lairds spend two years at Sangiramik, where Robert Laird worked to develop the oil field. "During all that time," Laird stated, "my wife never saw a white woman." The Lairds were described in the pages of the Toronto Weekly Star as "Petrolia Orientalists." Mrs. Laird praised the Dutch colonial cuisine. "We had some great banquets," she declared, "when we went to Batavia on our holidays. I've seen as many as ten boys

${ }^{66}$ Petrolia Advertiser, 11 April 1900; Robert Reade, "Memories of Malaya," Toronto Star Weekly, 30 January 1932.

${ }^{67}$ Ann Laura Stoler, "Carnal Knowledge and Imperial Power: Gender, Race, and Morality in Colonial Asia," in Joan Wallach Scott., ed., Feminism and History (Oxford and New York 1996), 221; Ann Laura Stoler, Capitalism and Confrontation in Sumatra's Plantation Belt, 1870-1979 (New Haven and London 1985), 31-5.

${ }^{68}$ Petrolea Topic, 22 November 1900.

69"The late John W. Crosbie," Petrolia Advertiser, 30 August 1899. 
standing at the table waiting their turn to serve us." ${ }^{70}$ Like their husbands, the wives of "foreign drillers" helped to promote the project of European imperialism.

The presence of more white women in colonial drilling communities after World War I put new demands on the oil companies to mark out their social space and to extend their measure of surveillance to ensure that white women were safe and native labourers were kept "under control." At Miri, Sarawak in July 1923, the Chinese broke out in rebellion, although according to Petrolia driller Bill Gillespie, no one knew exactly why they rebelled or what they intended to do. When it was over twelve Chinese labourers were dead, and several more died in hospital. Two Europeans, both state officials, were also hurt. ${ }^{71}$ In the aftermath of the Miri riot, the General Manager of the Sarawak Oilfields Limited issued a memorandum instructing its European employees "as far as possible to be impartial in their dealing with Members of the Staff and Labour Force of the various Nationalities." In the event of further rioting, the married Europeans were instructed to remain with their wives and families while the bachelors were ordered to gather together at one of the bungalows. ${ }^{72}$ In the oilfields of Bomeo and Peru during the 1920 s, separate white enclaves of company housing were constructed to protect the wives and children of foreign drillers.

Although women occupied a marginal position in oil production, they were the bearers of elevated moral standards in these insulated and isolated social spaces. In the 1920s oil companies and colonial administrators were rethinking the ways in which their authority should be expressed. The creation of European-like environments and the presence of white women were intended to insulate the men from the contamination of sexual contact with native women. ${ }^{73}$ "An Old Petrolia Boy" writing from Borneo in 1922 reported that "Miri has got to be a miniature of what Petrolia was in the old days," during the oil boom of the latter 19th-century. The white drillers' community in Miri had three clubs, two of them with billiard tables and dancing floors, and a church. The company had the latest "picture shows" brought in for the entertainment of the drillers and their families. ${ }^{74}$ At least three Petrolia men who departed as bachelors married English women and came home with families. A few single women were employed as stenographers and nurses by the oil companies. In a letter dated 19 November 1920 , and subsequently published in the Petrolia Advertiser-Topic, William Gillespie informed those at home of "A Happy Event in Borneo." A.E. Haley one of the "Petrolia Boys," had married Miss Stonehouse, of Hull, England in the Court House at Miri.

\footnotetext{
${ }^{70}$ Reade, "Memories of Malaya."

${ }^{71}$ Victor Lauriston, "Bill Gillespie Comes Home," The London Advertiser, 28 August 1926.

${ }^{72}$ Copy of Memorandum, Sarawak Oilfields Limited, Miri, 11 July 1923. My thanks to Kathleen Gillespie of Petrolia, Ontario for providing me with this document.

${ }^{73}$ Stoler, "Carnal Knowledge," 239-44.

${ }^{74}$ Petrolia Advertiser-Topic, 16 March 1922, 27 April 1922, 30 November 1922, 22 October 1925.
} 


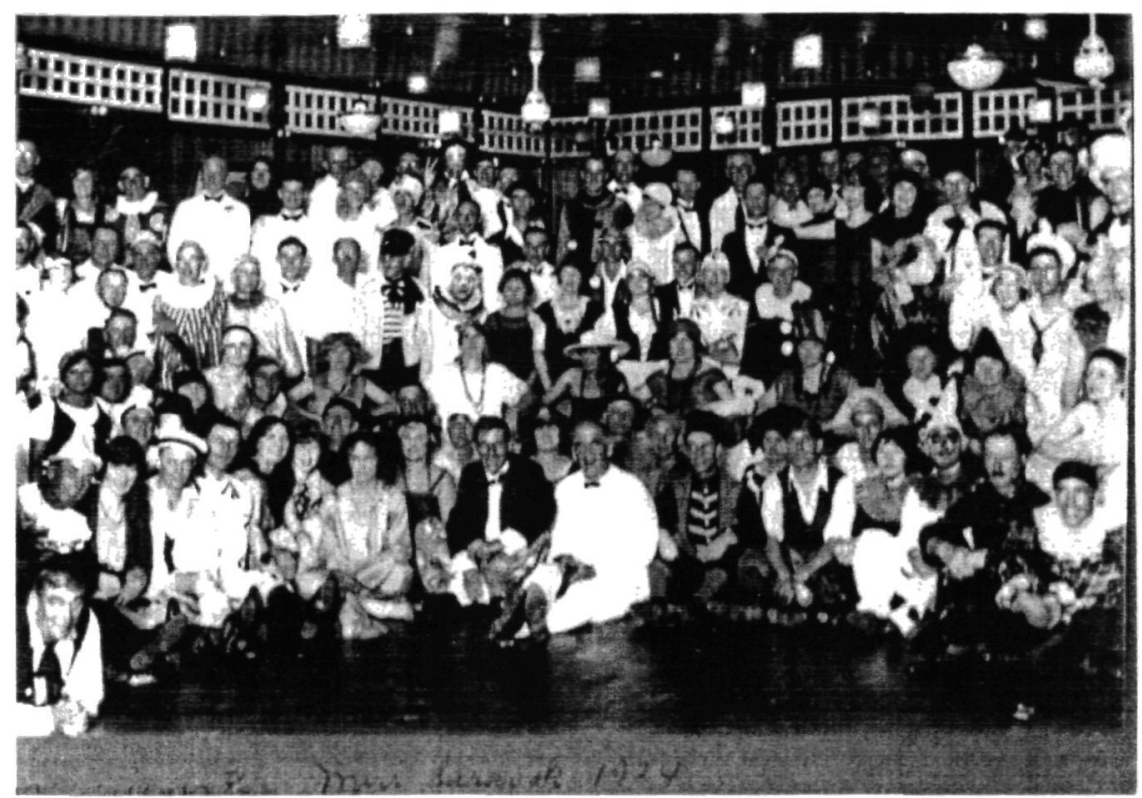

Figure 3. New Year's Eve Celebration at the Company Club in Miri, Borneo, 1924.

The departure from Miri of one Petrolia woman, Mrs. John Blake, in July 1921 was especially lamented by the drillers. Mrs. Blake organized Christmas dinners where she gathered all of the single men. ${ }^{75}$ As part of the project of reinventing domesticity in the colonies of oil exploitation, Enniskillen drillers and their families celebrated Western Christian holidays. "One of the Boys" recounted the Christmas celebration held in Miri in 1922 in a letter to the editor of the Petrolia Advertister-Topic. A Christmas tree was decorated for the children and all the latest toys were imported from England for the youngsters. "Christmas Day was much as it is at home, but without the cold and snow," the driller wrote. "Church in the afternoon, dancing early in the evening at the Rest House and then everyone off to the various dinner parties, music, song and story, until the wee small hours of the morning."76 Similarly, Vola Braybrook, who accompanied her husband to Venezuela recalled that "each family would take in a bachelor or two over the Christmas and Easter holidays." "77

The households maintained by the wives of "foreign drillers" became sites for the reinvention of European ideals of domesticity. Class formation and the process

\footnotetext{
${ }^{75}$ Advertiser-Topic, 15 September 1921.

${ }^{76}$ Advertiser-Topic, 22 February 1923.

${ }^{77}$ Vola Braybrook, taped interview with Charles Whipp, 8 June 1984. Copies of all Charles Whipp's interview tapes are available at the Petrolia Discovery Museum, Petrolia, Ontario.
} 
of racialization were also mutually constitutive among the wives of "foreign drillers." In 1921, Agnes Miller accompanied her husband Orville "Dick" Miller to Venezuela. "They spoke Spanish and I couldn't speak a work of Spanish at all," Miller remembered. "Anyway we took lessons in Spanish from a man who knew Spanish and spoke good English." During the time they lived in Venezuela the Millers had two maids: "one was a cook and one cleaned the house. Polished the shoes." They also had a male servant named Dabro, who washed Dick Miller's car. Agnes Miller indicated that having servants "was part of the game." Building on the dominant White-European discourse of racial difference, Agnes Miller described the native servants as "thievish."

The Miller's enjoyed a class status and a standard of living above that of the families of drillers who remained in Enniskillen township. Dick Miller had his own car. He earned \$225 (US dollars) a month from his job as a tool dress, where he put the final finishing on the drilling tools, shaped the drill bits, and repaired used and damaged drilling equipment in the field; this was twice the amount he would have made back home. He was soon made a driller where he earned even more. Agnes Miller was relieved of many of the housekeeping duties that the wives of drillers who remained at home still had to perform. With two maids performing the bulk of the housekeeping, Agnes Miller was free to spend afternoons playing bridge with the drillers' wives. The Millers also spent their evenings at the company club. The cook would have dinner prepared for them when they returned. ${ }^{79}$

Vola Braybrook recalled some of the difficulties she experienced in reinventing domesticity while living abroad: "You see they didn't think anything of cleaning a milk pitcher in the kitchen and taking the rag and wringing it out and cleaning all the hand basins and the bathroom equipment."Cleanliness was at the heart of the drillers' wives ideal of domesticity in the "contact zone." Although the voice of the native women domestics was obviously excluded from the oral histories provided by the wives of Enniskillen's "foreign drillers," their accounts suggest that the experience was not perceived by the native women in the same way. Vola Braybrook noted that when a "local girl" came into the household she was usually frightened. ${ }^{80}$

The racialization of class difference among the families of "foreign drillers" and their native servants was not always fraught with tension and conflict. Dorothy Stevenson, who went to Venezuela when she was only eight years old, claimed that her mother "took the maid into the family." The maid shared meals with Dorothy and her mother. "She didn't eat with us at night when my Dad was there, but all the rest of the time and we were a family," Dorothy recalled. It would seem that in some instances gender muted, but did not erase, relations of power constructed on racial and class lines which were central to the invention of imperialism. It is also possible that in comparison to the colonial oil fields of the East Indies, for instance, racial

\footnotetext{
${ }^{78}$ Agnes Miller, taped interview with Charles Whipp, 5 June 1984.

${ }^{79}$ Miller Interview.

${ }^{80}$ Braybrook interview.
} 
lines were less clear in South America. Dorothy Stevenson suggested that the rural working-class background of the drillers encouraged harmonious relations with the natives: "they were normal farm boys ... I know Canadians were well liked."81

The children of Enniskillen's "foreign drillers" usually remained with their parents in "foreign fields" until they were of school age whereupon they returned home. Children were believed to be particularly impressionable. Thus, they were sent back to Canada to avoid the "danger," and cultural contagion, that was thought to arise from the prolonged interaction of white children with natives. Most of the children were accompanied by their mother and attended local schools. In the fall of 1923 one Petrolia school teacher remarked that during the previous year she had taught children who have lived in every continent but Australia. "A geography lesson was full of interest and life," she remarked. ${ }^{82}$

In October 1923, the drilling community established by the International Petroleum Company at Negritos, Peru, reportedly contained 8,146 Peruvians and 192 "foreigners." The "foreigners" were comprised of 90 men, 51 women, and 51 children. The company provided racially segregated schooling organized into three units: white, Peruvian, and Anglo-Peruvian. A separate school was provided for white European and North American children, commencing with primary grade and finishing with third form at the secondary school level. The teachers were engaged in the USA. The Peruvian school was under the direction of a Peruvian superintendent. Children of "mixed parentage" - one Peruvian parent and one English, Danish, or Spanish parent - attended the Anglo-Peruvian school. The company provided the books and supplies for the school children. ${ }^{83}$ Agnes Miller returned to Petrolia shortly after her daughter Dorothy began school. "She wasn't going to get very much Canadian education in Colombia," Miller stated. ${ }^{84}$

Enniskillen's "foreign drillers" enjoyed class and racial privilege in the colonies of oil exploitation. This was sustained not only through formal means such as the provision of company housing, schools, and "whites only" social clubs, but in more informal ways including the practice of greeting fellow Enniskillen drillers at the dock as they arrived in "foreign fields." There were so many Petrolians in Borneo in the early 1920s that Mrs. Alfred Webb, in a rare letter from the wife of a "foreign driller" published in the local newspaper, commented that "it does not seem that we are really in a foreign country." 85

${ }^{81}$ Dorothy Stevenson, taped interview with Charles Whipp, 5 June 1984.

${ }^{82}$ Petrolia Advertiser-Topic, 25 October 1923.

${ }^{83}$ Petrolia Advertiser-Topic, 29 May 1924; 24 November 1927.

${ }^{84}$ Agnes Miller, taped interview with Charles Whipp, 5 June 1984.

${ }^{85}$ Petrolia Advertiser-Topic, 2 November 1922. 


\section{Domesticity and Displays of Imperial Spectacle at Home}

According to Vola Braybrook, the wives of Enniskillen's "foreign drillers" did not really want to go abroad: "They wanted to raise the children among the relatives and in Canada," she stated. ${ }^{86}$ Amold Thompson's father drilled in Egypt, Cuba, and India during the period surrounding World War I. Thompson described the impact that the long periods of separation had on familial relationships:

When I was six years old my father left for foreign fields. From then on my father was a stranger. People will find it difficult to accept that. But this is a fact of family life, not just with my family, but with a number of families in Petrolia ... So therefore our mothers brought us up ... When our father came home ... I'm going to speak for myself. When my father come [sic] home he was just another man. I didn't know him. I didn't know what to talk to him about. He didn't know what to talk to me about because we had nothing in common. ${ }^{87}$

It was not unusual for the children of Enniskillen's "foreign drillers" to report that their fathers were complete strangers when they returned home after an absence of three or more years. Arnold Thompson also revealed that relations between husbands and wives were oftentimes strained after a separation of several years.

In their reminiscences the children of foreign drillers remember their mothers as being extremely busy and lonely. Many wives relied on extended kinship networks for support during the long periods when their husbands were absent. Dorothy Stevenson recalled that her father would no sooner arrive home, then he would announce that he had signed another contract to drill abroad. "And then mother would pack up her furniture and go home to her mother," Stevenson stated. Her grandfather was the "man in the house," and he became a "surrogate father" to Dorothy. ${ }^{88}$

Many of the wives of "foreign drillers" were active in local church groups and attended services every Sunday. Ev Brimmer revealed that her mother used to invite the Ladies' Aid from the Presbyterian Church to their home for afternoon tea while her father was absent abroad. ${ }^{89}$ The wives of "foreign drillers" also organized informal bridge groups and held quilting bees. Extra-marital sexual relations were allegedly rare, although many of those interviewed were children at the time and thus were unlikely to be aware of any sexual liaisons involving their mothers. "You know women lived a very restricted life," Dorothy Stevenson indicated. "They just weren't free to wander around as we do now."90

\footnotetext{
${ }^{86}$ Vola Braybrook, taped interview with Charles Whipp, 8 June 1984.

${ }^{87}$ Arnold Thompson, taped interview with Charles Whipp, 16 April 1984.

${ }^{88}$ Stevenson interview.

${ }^{89}$ Ev Brimmer, taped interview with Charles Whipp, 21 May 1985.

${ }^{90}$ Stevenson interview.
} 
The homes of the "foreign drillers" in Petrolia and surrounding Enniskillen township became a space for the display of imperial spectacle. The drillers had postcards made in photographic studios which they mailed back home. "Photography became the servant of imperial progress," Anne McClintock suggests. In the colonial postcard, "time is reorganized as spectacle; history is organized into a single linear narrative of progress." The postcard "Petrolia Drillers in Singapore" (Figure 4) was staged in a photographic studio, and was probably paid for by the men sitting on the rickshaw, namely Bill McCrae on the left and Bill McEwen on the right. Imperial authority is elaborately staged in the photograph. The drillers are displayed in a position of prominence and authority in the white summer dress of a gentleman on top of a rickshaw drawn by an Oriental boy. In contrast to the finery of the two drillers, the boy wears a rough straw hat and is bare chested.

The drillers also purchased "curios" and had them shipped back home. As Ev Brimmer recalled:

We would get funny things. It would seem to a kid to be funny things ... One I used to see on the wall Mother would tell me was a sword fish's tongue. I don't know whether it was a tongue. It had horrible teeth all over it. It was hanging on the wall. There was a war club from Persia strapped on the wall. And then one day I walked in the living room. We called it the parlor then. And on the floor were two of the most beautiful Persian rugs. Just absolutely gorgeous. $^{92}$

The curiosities, the postcards, and the travel chronicles all added to the prestige of the "foreign drillers" in the community.

In addition to the position of authority the drillers attained in the community as travelled men, they also earned high wages. "We weren't short of anything you know," Ev Brimmer stated, "we were I guess well off":

Persian rugs, cherry whatnots, cherry wardrobes. We had beautiful things. A player piano. The newest thing that came out we would have it. Player piano, Persian rugs ... Limoge china that we ate off every day. Limoge china. I remember breaking the gravy boat, knocking the gravy boat off the platter. And Momma, just ordinary. Just ordinary. Limoge. I would give my eye teeth for some of that china we ate off now. And we just took it for granted. ${ }^{93}$

Most drillers made arrangements to send money home regularly every month. Dorothy Stevenson recalled that her father deposited "house money" into an account set up at the Petrolia branch of the Bank of Toronto. ${ }^{94}$ The wives of the "for-

\footnotetext{
${ }^{91}$ McClintock, Imperial Leather, 15.

${ }^{92}$ Brimmer interview.

${ }^{93}$ Brimmer interview.

${ }^{94}$ Stevenson interview.
} 


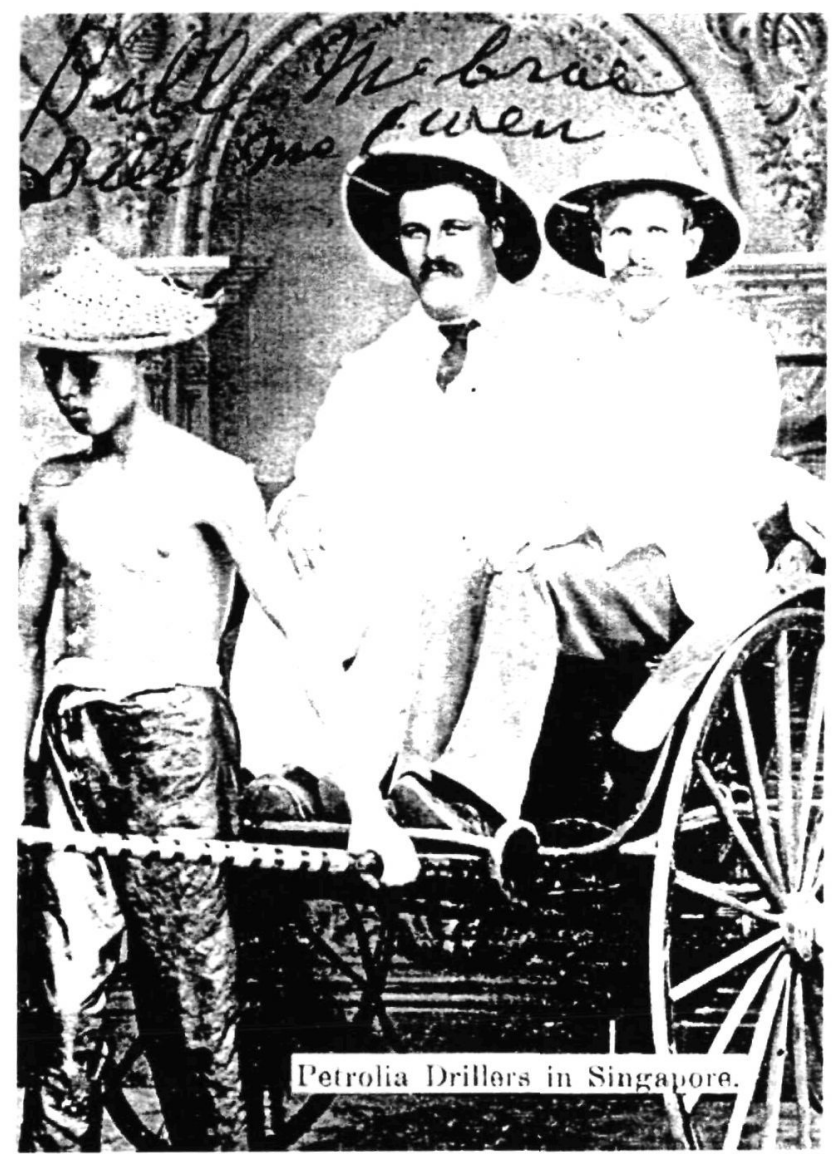

Figure 4. Petrolia Drillers in Singapore.

eign drillers" continued to manage expenditures for household consumption in the absence of their husbands.

The local economy and imperial capitalist expansion were interwoven in the process of class formation. As another crew of Enniskillen drillers set off for Borneo in May 1899, the Petrolia Advertiser commented: "Our men go abroad unloosing the riches of the earth in strange lands, but they almost all come back to Petrolia to enjoy the rich fruits of their labor, much to the advantage of our town." Twenty-five years later, in a letter signed "One of the Old Timers," a retired driller extolled the economic benefits to the community that resulted from the employment of local drillers abroad. The "Old Timer" revealed that " $\$ 15,000$ or more a 
month comes back to Petrolia from these drillers, who exile themselves for years on end, that they may have a 'stake' for their old age."95

While it was not possible to trace the career path of all of Enniskillen township's "foreign drillers," it would appear that employment abroad resulted in elevation into the ranks of the middle class for a substantial number of "foreign drillers." A handful of Enniskillen's "foreign drillers" became wealthy men, and like William McGarvey never returned to the community. By the 1920 s some of the drillers with experience in "foreign fields," and who had learned drilling at what was by then referred to locally as the "Petrolia Drillers University," attained supervisory and management positions with large international oil companies. George W. Brake learned the trade in the oil fields of Petrolia from his father and grandfather both of whom were oil drillers. In 1902, Brake went to the Dutch East Indies and remained there until 1905, when he signed a contract with a syndicate to drill in Egypt. When World War I broke out in 1914, Brake was drilling in Venezuela. During the War he relocated to Peru where he became superintendent of the production department. Another local driller, Joseph Burns of Oil Springs, was superintendent of the drilling department with the International Petroleum Company in Peru. In 1922, Fred Sander was made the general superintendent of a refinery operated by the Royal Dutch Oil Company in Tampico, Mexico. ${ }^{96}$ Several "foreign drillers" spent most of their adult working lives abroad and managed to save enough money to retire to Petrolia or Samia. Some "foreign drillers" were able to purchase farms, start small businesses, or purchase their own local oil properties. Others went to work locally at the Canadian Oil Refinery in Petrolia, or relocated to Sarnia where they found employment. For instance, John Keene drilled for oil and water in Egypt, Borneo, Sumatra, Venezuela, and at various points in Canada during the early decades of the 20th century. Upon returning home he was hired as an engineer in the Petrolia fields. He then went to work at the Petrolia Wagon Works before securing a position in the Canadian Oil Refinery, from which he retired in $1943 .{ }^{97} \mathrm{~A}$ considerable proportion of Enniskillen township's "foreign drillers" rejoined the ranks of the working-class upon returning home. Dorothy Stevenson noted that the men who were unable to save any of their wages while working abroad "had a problem when they came home, and they had to work for somebody else." 98

Local manufacturers and retailers also benefitted from the imperial project in colonial exploitation. The Oil Well Supply Company, which still exists today, provided drilling tools and rigs for colonial oil exploitation from its earliest stages. ${ }^{.9}$ In

${ }^{95}$ Petrolia Advertiser, 17 May 1899; Petrolia Advertiser-Topic, 18 January 1924.

${ }^{96}$ Petrolia Advertiser-Topic, 20 July 1922, 15 June 1922, 30 November 1922, 29 October 1925, 8 November 1928.

${ }^{97}$ Petrolia Advertiser-Topic, 3 December 1953.

${ }^{98}$ Stevenson interview.

${ }^{99}$ On 26 September 1890, the Petrolea Topic reported: "The Oil Well Supply Co, of Petrolea, are this week, shipping a large consignment of drilling tools, supplies, etc., to East 
January 1900 , during a period when the local economy was in desperate straits in the aftermath of the relocation of the Imperial Oil Refinery to Sarnia and the decline in production in the local oil fields, the Oil Well Supply Company enlarged its blacksmith and machine shop plant in Petrolia to meet the demands of the foreign drilling trade. ${ }^{100}$ This, in turn, provided employment for a highly specialized and skilled body of local workers. The local economy and global imperialist capitalist expansion were mutally dependent upon one another.

\section{Conclusion}

On 9 August 1900, the Petrolea Topic reported that a curious example of the way in which the town's citizens were scattered over the world had occurred the previous day when Irwin Joyce and John Hughson met on the street corner on Greenfield Street. The last time the two men had met was twelve years earlier in Galicia. "Since then both have acquired a fine crop of grey hair, Mr. Joyce in Australia and Mr. Hughson in various countries, but during the last two years in Sumatra." Hughson had just returned home from Sumatra by way of Honolulu and Vancouver, and Joyce was on his way back to Australia the following week. "It is an old story," the reporter for the Petrolea Topic remarked, "but there is not a town in Canada that has pioneer representatives in so many quarters of the world as Petrolea, who all look back as fondly and return as eagerly to their native town."101

The travel writings produced by Enniskillen oil drillers were part of the process by which European imperialism was produced for home consumption. In their travel narratives Enniskillen's "foreign drillers" constructed a cultural space in which they disavowed the creative agency of non-white native Others using prior constructions of racial and gender power which further sustained European imperialism. A distinction between exotic Eastern cultures and home, which incorporated a racial hierarchy in which non-white Eastern women were usually defined as sexual predators, was central to the colonial discourse articulated by Enniskillen township's "foreign drillers" through their travel writings. As British subjects and Anglo-Canadians, travel and travel writing helped to define Enniskillen drillers as both colonizers and colonized. Travel abroad, moreover, bestowed upon them a measure of prestige and authority at home. As agents of imperialism, Enniskillen drillers became something of an "overclass" by virtue of their "whiteness," "Britishness," and skill in drilling.

The mapping of colonial masculinities for readers back home in Enniskillen township occurred in a dialectic of "home" and "away," thus dissolving the polarities between "home" and "foreign fields," which the oil drillers themselves some-

India. This firm secured large contracts in those foreign countries, and have been working night and day for some weeks in order to fill orders."

${ }_{100}^{108}$ Petrolia Advertiser, 24 January 1900.

${ }^{101}$ Petrolea Topic, 9 August 1900. 
times articulated. The colonial oil fields were a space for the reinvention of Victorian ideals of domesticity. Domesticity was one "civilizer." Labour was another means by which white male domination was achieved in the colonial oil fields. Enniskillen drillers supervised gangs of native labourers in the colonial oil fields. Labour and domesticity were also means by which the mutually constitutive processes of class formation and racialization occurred in the colonial oil fields. Enniskillen drillers enjoyed a position of class privilege, which no doubt would have eluded them had they spent their entire working career at home. In their colonial discourse, Enniskillen's "foreign drillers" articulated a detailed racial hierarchy linking skin colour and physical prowess with moral character. This in turn allowed them to label different groups of natives as more or less useful as labourers in the oil fields.

The wives and children of "foreign drillers" also travelled to "foreign fields," particularly after World War I. Domesticity and the family patriarchy were re-established abroad. The wives of "foreign drillers" were responsible for making a home while away. In their role as homemakers, they reinforced the project of imperialism and its hierarchies of race and class. The women who went abroad, however, were more privileged than the wives of "foreign drillers" who remained at home. Unlike their counterparts at home, the wives of "foreign drillers" had native servants and were relieved of some of the burdens of housekeeping.

The local economy of Enniskillen township benefitted from foreign drilling. While abroad, most of the "foreign drillers" sent money home regularly to support their wives and families. Local manufacturers and retailers profited from the global business in colonial oil development. The homes of Enniskillen drillers became a place for the display of imperial masculinity; further forging the connections between "home" and "empire" Enniskillen drillers shipped curios home. Whether it be head hunters' knives from Borneo, or snake skins from India, these "curiosities" further attested to the heroic acts of the "foreign drillers" which they documented in their travel letters, and allowed them to attain the privileged status of world travellers at home.

As one passes through the present-day town of Petrolia, the legacy of the "foreign drillers" can be found in some of the street names derived from the "foreign fields" where Enniskillen drillers were employed, namely Oozloffsky, Ignatieff, and Valentia streets. Petrolians are proud of their heritage as "The Town of World Travelers."

I would like to thank Barbara and Frank Burr, Helen Maddock, Greg Kealey, Alan Sears, Christina Simmons, Bruce Tucker, Leslie Howsam, and Lynne Phillips for their intellectual input and support. An earlier version of this paper was presented at the British Association of Canadian Studies Conference in Edinburgh, Scotland, 
12 April 2000. I thank the audience for their comments, many of which have been incorporated here. Finally, I wish to gratefully acknowledge the financial support of SSHRC and the University of Windsor.

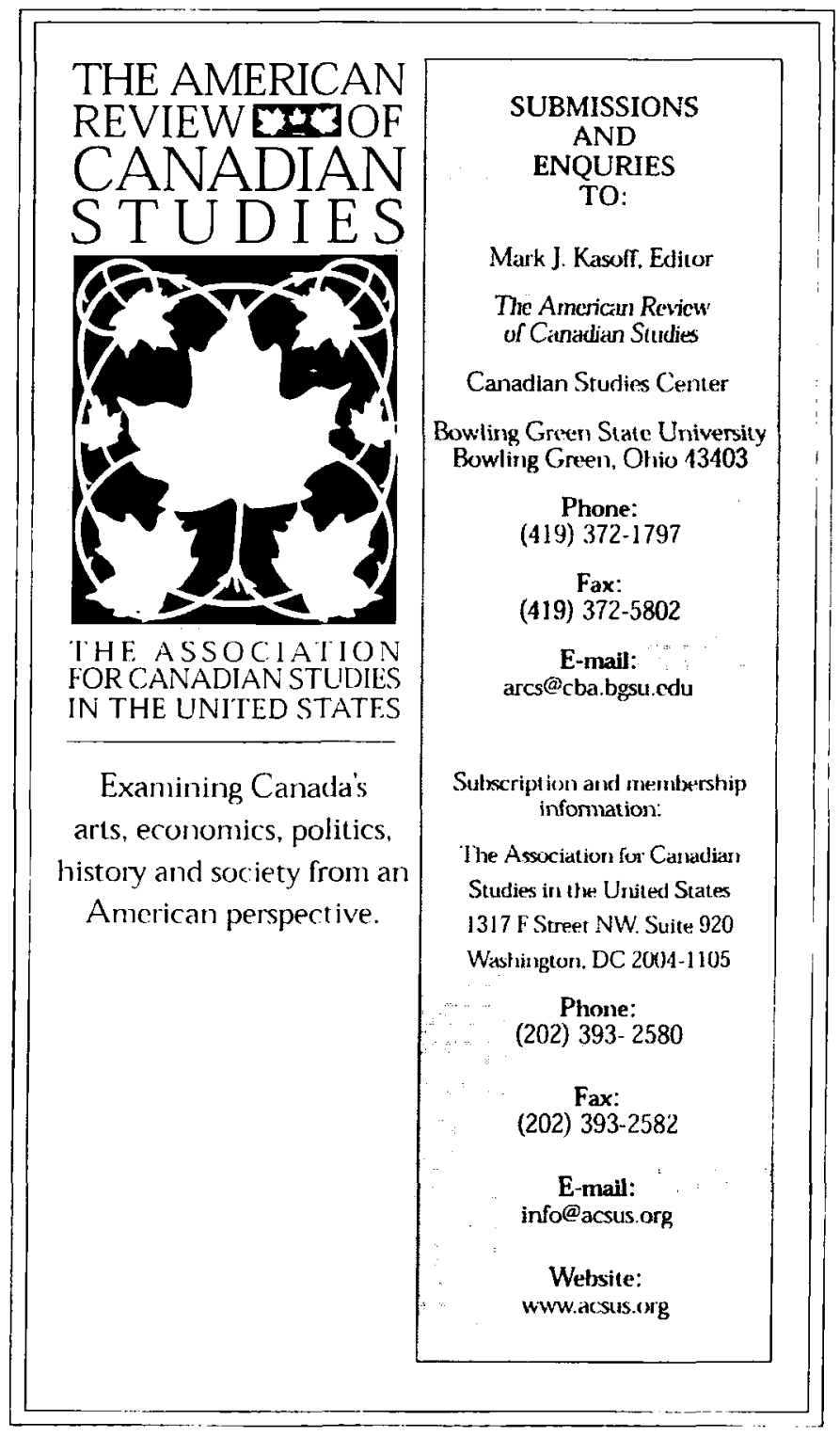

